\title{
Results and goals
}

\section{Milton Artur Ruiz}

Editor in Chief, Revista Brasileira de Hematologia e Hemoterapia
Submitted: $5 / 3 / 2011$

Accepted: 5/4/2011

Corresponding author: Milton Artur Ruiz Rua Catarina Nucci Parise 760 15090-470 - São José do Rio Preto, SP, Brazil

milruiz@yahoo.com.br

www.rbhh.org or www.scielo.br/rbhh

DOI: $10.5581 / 1516-8484.20110023$
The last issue of the Revista Brasileira de Hematologia e Hemoterapia (RBHH) Journal of Hematology and Hemotherapy - was the result of a sequence of events that began after the emergence of the new Qualis classification established by the Coordenação de Aperfeiçoamento de Pessoal do Ensino Superior (CAPES) of the Brazilian Government that ranks scientific journals. ${ }^{(1)}$

All journals were reclassified using just the Impact Factor (IF) of Thompson Reuters; those that were not indexed to the Institute for Scientific Information (ISI/JCR) were discriminated against and demoted as second class publications. This had a great impact on the Brazilian academic scene as individual productivity is now measured by the new classification criteria and the IF started to have a great bearing in determining the quality of post graduate programs in the country which are based on the publications of university professors. The implementation of this measure caused reactions with several meetings being organized supported by the Brazilian Medical Association (AMA) and the Brazilian Association of Scientific Editors (ABEC). These meetings debated the decisions of CAPES and resulted in several joint publications that were printed in many national scientific journals. $^{(2,3)}$ Additionally, with the aim of stressing the true value of Brazilian journals, the use of other parameters to classify journals were discussed in the debates. One suggestion was to adopt the indices of SCImago Journal Rank (SJR) and SciELO. ${ }^{(4)}$ The reason why CAPES should adopt these other two indices is related to the fact that the use of the IF alone is not recommendable and because, as was shown by the Editor-in-Chief of the journal Clinics, the IF and these two other indices overlap; if this combination were used by CAPES, some journals, including the Revista Brasileira de Hematologia e Hemoterapia, would be reclassified from B4 to B2. ${ }^{(4)}$ Figure 1 and Table 1 show the correlation between the ISI/JCR and SCImago impact factors and a list of 138 journals excluded by the Qualis criteria including the RBHH.

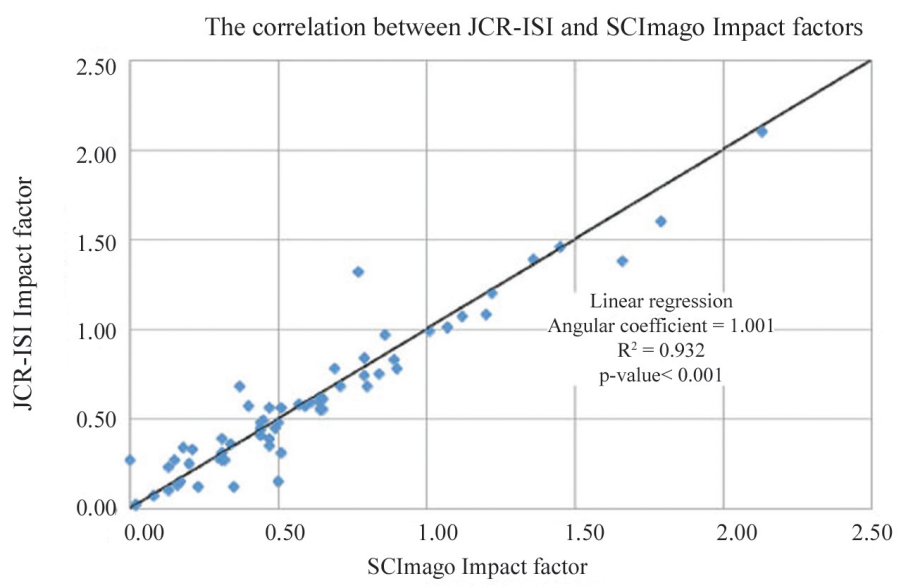

Figure 1 - Correlation between Journal Citation Reports (ISI - Thompson) and SCImago (2009) impact factoŕs for the 64 Brazilian journals indexed in both and with values greater than zero. The identity between the metrics is practically absolute. The angular coefficient indicates an angle of $45^{\circ}$ (meaning identity) and the correlation $\left(\mathrm{R}^{2}=0.932\right.$; p-value $\left.<0.001\right)$ is almost perfect

The RBHH supports the adoption of these three parameters to evaluate Brazilian journals. The new Qualis classification of CAPES took us at the journal, out of our comfort zone. By early 2010, the recently sworn in board of directors of the Associação Brasileira de Hematologia e Hemoterapia (ABHH), through its scientific department, met with the Editorial Policy Council attended by prestigious hematologists from around the country with the aim of discussing the future of the journal. The ten years of uninterrupted publications of the RBHH which had substituted the Bulletin of the Sociedade Brasileira de Hematologia e Hemoterapia (published since 1973) as the official vehicle of scientific communications of Brazilian Hematology, was evaluated under a critical eye and two alternatives were 
Table 1- The SCImago Impact Factor of 138 Brazilian Journals excluded in the recent Qualis classification (Simulation using 2009 figures)

\begin{tabular}{|c|c|c|}
\hline Rank & Title & Citations/document SCImago \\
\hline 1 & Acta Scientiarum - Agronomy & 1,19 \\
\hline 2 & International Braz J Urol & 1.09 \\
\hline 3 & Revista do Instituto de Medicina Tropical de São Paulo & 1.08 \\
\hline 4 & Brazilian Journal of Plant Physiology & 1.05 \\
\hline 5 & Annual Review of Biomedical Sciences & 0.85 \\
\hline 6 & Jornal Brasileiro de Pneumologia & 0.85 \\
\hline 7 & Revista Brasileira de Epidemiologia & 0.73 \\
\hline 8 & Brazilian Journal of Cardiovascular Surgery & 0.72 \\
\hline 9 & Acta Ortopedica Brasileira & 0.71 \\
\hline 10 & Brazilian Journal of Biology & 0.69 \\
\hline 11 & Brazilian Dental Journal & 0.67 \\
\hline 12 & Ciência e Saúde Coletiva & 0.58 \\
\hline 13 & Materials Research & 0.55 \\
\hline 14 & Brazilian Oral Research & 0.53 \\
\hline 15 & Arquivos de Gastroenterologia & 0.49 \\
\hline 16 & Revista Brasileira de Saúde Materno Infantil & 0.49 \\
\hline 17 & Acta Botanica Brasilica & 0.48 \\
\hline 18 & Phyllomedusa & 0.48 \\
\hline 19 & Acta Sientiarum - Biological Sciences & 0.46 \\
\hline 20 & Revista Brasileira de Medicina do Esporte & 0.46 \\
\hline 21 & Revista Brasileira de Botânica & 0.45 \\
\hline 22 & PRO-FONO: Revista de Actualização Cientifica & 0.44 \\
\hline 23 & Revista Brasileira de Engenharia Agrícola e Ambiental & 0.41 \\
\hline 24 & Engenharia Agrícola & 0.40 \\
\hline 25 & Arquivos Brasileiros de Oftalmologia & 0.38 \\
\hline 26 & Biota Neotropica & 0.38 \\
\hline 27 & Radiologia Brasileira & 0.38 \\
\hline 28 & Revista Brasileira de Otorrinolaringologia (English ed.) & 0.38 \\
\hline 29 & Revista Brasileira de Sementes & 0.38 \\
\hline 30 & Acta Amazonica & 0.37 \\
\hline 31 & Ciência Rural & 0.36 \\
\hline 32 & Arquivo Brasileiro de Medicina Veterinária e Zootecnia & 0.35 \\
\hline 33 & Pan-American Journal of Aquatic Sciences & 0.35 \\
\hline 34 & Revista Brasileira de Ginecologia e Obstetrícia & 0.35 \\
\hline 35 & Acta Paulista de Enfermagem & 0.34 \\
\hline 36 & Eclética Química & 0.34 \\
\hline 37 & Papéis Avulsos de Zoologia & 0.33 \\
\hline 38 & Revista Brasileira de Plantas Medicinais & 0.31 \\
\hline 39 & Bragantia & 0.29 \\
\hline 40 & Revista Árvore & 0.29 \\
\hline 41 & Revista Brasileira de Anestesiologia & 0.29 \\
\hline 42 & Revista de Psiquiatria Clínica & 0.29 \\
\hline 43 & Jornal Brasileiro de Psiquiatria & 0.28 \\
\hline 44 & Journal of Microwaves and Optoelectronies & 0.27 \\
\hline 45 & Pesquisa Operacional & 0.27 \\
\hline 46 & Scientia Forestalis/Forest Sciences & 0.27 \\
\hline 47 & Revista Brasileira de Ciência Avícola & 0.26 \\
\hline 48 & Revista Brasileira de Hematologia e Hemoterapia & 0.26 \\
\hline 49 & Revista de Economia Política & 0.26 \\
\hline 50 & Cerâmica & 0.25 \\
\hline 51 & Estudos Avançados & 0.25 \\
\hline 52 & Interface: Comunicação, Saúde, Educação & 0.25 \\
\hline 53 & Online Brazilian Journal of Nursing & 0.24 \\
\hline 54 & Boletim de Geociências - Petrobrás & 0.23 \\
\hline 55 & HAHR - Hispanic American Historical Review & 0.23 \\
\hline 56 & Opinião Pública & 0.23 \\
\hline 57 & Revista Brasileira de Ciências Farmacêuticas & 0.23 \\
\hline 58 & Cadernos de Pesquisa & 0.22 \\
\hline 59 & Anais Brasileiros de Dermatologia & 0.21 \\
\hline 60 & Journal of Public Child Welfare & 0.21 \\
\hline 61 & Lundiana & 0.21 \\
\hline 62 & Revista de Ciências Farmacêuticas Básica e Aplicada & 0.21 \\
\hline 63 & Tropical Plant Pathology & 0.21 \\
\hline 64 & Jornal Vascular Brasileiro & 0.20 \\
\hline 65 & Revista Brasileira de Enfermagem & 0.20 \\
\hline 66 & Jornal Brasileiro de Patologia e Medicina Laboratorial & 0.19 \\
\hline 67 & História, Ciências, Saúde - Manguinhos & 0.18 \\
\hline 68 & Revista de Psiquiatria do Rio Grande do Sul & 0.18 \\
\hline 69 & Geociencias & 0.17 \\
\hline 70 & Revista Brasileira de Reumatologia & 0.17 \\
\hline
\end{tabular}

considered; to stop to print altogether or to invest with the objective of making the RBHH an internationally respected journal. The few advocates who wanted to stop to print justified this based on the limited international representation which is correct if you take into account that the RBHH is not indexed to the most prestigious international databases and when you compared it to other medical journals with high impact factors. However, the decision of ABHH was to honor the existing journal and to invest in it based on the apparently simplistic view of one participant in the discussions who 
questioned: "why destroy it? It is easier to improve what we already have." And so the meeting ended. Since then the ABHH has increased its support - a description of most of the steps taken at the journal was presented in an editorial in the last issue; ${ }^{(5)}$ the most important changes were the professionalization of the journal and the creation of the Internal Editorial Committee.

As a result, the first issue of volume 33 has a more elaborate layout, but even more importantly, it was more painstakingly checked to improve the content and overall quality. On observing the profile of the excluded journals in SCImago, including the RBHH, we see that there is a large number of publications in regular issues and special supplements every year that are quotable (original and review articles), but that the high number reduces the impact factors of both SCImago and SciELO. This meant that measures needed to be taken with improving the quality of the journal becoming our true goal. Thus, decisions were taken, not only in respect to preparing publishing, online submission and review manuals that are currently being developed, but also to improve the publicity of the journal with the goal of including the RBHH in international databases for it to be an active participant in the development of hematology and transfusion therapy.

\section{References}

1. Brasil. Ministério da Educação http://www.capes.gov.br/avaliacao/qualis

2. Brazilian Editors of Scientific Magazine. Changes in the criteria of Qualis. Rev Bras Hematol Hemoter. 2010;32(3):189-91.

3. Brazilian Editors of Scientific Magazine. Journal classification in the Qualis/Capes System - a change is urgently required. Rev Bras Hematol Hemoter. 2010;32(1):1-3

4. Rocha e Silva M. Reflexões críticas sobre os três erres nos periódicos brasileiros excluídos. Clinics. 2011;33(1):3-7

5. de Souza CA. The evolution of the "Revista Brasileira de Hematologia e Hemoterapia" to meet the challenges of a new era. Rev Bras Hematol Hemoter. 2011;33(1):1-2

$\mathrm{XXX}$ 